\title{
Spermatid-Specific Linker Histone H1-Like Protein
}

National Cancer Institute

\section{Source}

National Cancer Institute. Spermatid-Specific Linker Histone H1-Like Protein. NCI

Thesaurus. Code C162869.

Spermatid-specific linker histone $\mathrm{H} 1$-like protein (231 aa, $\sim 26 \mathrm{kDa}$ ) is encoded by the human H1-9 gene. ThisF1:F143tein is involved in chromatin condensation during spermatogenesis. 